Brazilian Journal

of Chemical

ISSN 0104-6632

Engineering

Printed in Brazil

www.scielo.br/bjce

Vol. 34, No. 03, pp. $671-680$, July - September, 2017

(cc) EY

dx.doi.org/10.1590/0104-6632.20170343s20150514

\title{
BACTERIAL CELLULOSE PRODUCTION BY Komagataeibacter hansenii ATCC 23769 USING SISAL JUICE - AN AGROINDUSTRY WASTE
}

\author{
H. L. S. Lima ${ }^{1}$, E. S. Nascimento ${ }^{1}$, F. K. Andrade ${ }^{2}$, A. I. S. Brígida ${ }^{3}$, \\ M. F. Borges ${ }^{2}$, A. R. Cassales ${ }^{2}$, C. R. Muniz', M. de S. M. Souza Filho', \\ J. P. S. Morais ${ }^{4}$ and M. de F. Rosa ${ }^{2 *}$ \\ ${ }^{1}$ Federal University of Ceará, Campus do Pici, 60455-760 Fortaleza, CE, Brazil \\ ${ }^{2}$ Embrapa Agroindústria Tropical, Rua Dra. Sara Mesquita, 2270, Planalto do Pici, 60511-110 Fortaleza, CE, Brazil \\ *E-mail: morsyleide.rosa@embrapa.br, Phone: +55 853391 7344; Fax: +55 8533917109 \\ ${ }^{3}$ Embrapa Agroindústria de Alimentos, Av. das Américas, 29.501, Guaratiba, 23020-470 Rio de Janeiro, RJ, Brazil \\ ${ }^{4}$ Embrapa Algodão, Rua Oswaldo Cruz, 1.143, Centenário, 58428-095 Campina Grande, PB, Brazil
}

(Submitted: September 9, 2015; Revised: January 14, 2016; Accepted: March 21, 2016)

\begin{abstract}
In this study, we have optimized production of bacterial cellulose (BC) by Komagataeibacter hansenii ATCC 23769 in a static cultivation using sisal juice, an agroindustrial residue, as substrate. Optimization of fermentation parameters has been carried out using the one-variable-at-a-time method. Effect of initial sugar concentration, $\mathrm{pH}$, nitrogen supplement, and cultivation time was evaluated. The influence of nitrogen source and quantity for bacterial cellulose production was studied using a central composite rotational design (CCRD). The highest production of BC $(3.38 \mathrm{~g} / \mathrm{L})$ was obtained after 10 days of cultivation, using sisal juice $(\mathrm{pH} 5)$ at $15 \mathrm{~g} / \mathrm{L}$ of sugars and supplemented with $7.5 \mathrm{~g} / \mathrm{L}$ of extract yeast. The cellulose production yield in selected sisal culture conditions was three times higher than the yield in synthetic medium, indicating that sisal juice is a suitable substrate for BC production.
\end{abstract}

Keywords: Bacterial cellulose, Sisal juice, Komagataeibacter hansenii, Agroindustrial waste, Nanotechnology

\section{INTRODUCTION}

The development of processes for the production and application of biodegradable materials within the scope of green chemistry has been seen as a way to increase the efficiency of conventional processes and ensure the safety of the environment. Among those biodegradable materials, bacterial cellulose is an easily obtainable carbohydrate polymer that has shown potential for application in several areas (Brown, 1986; Panesar et al., 2012; Wu et al., 2013).

Bacterial cellulose $(\mathrm{BC})$ presents unique properties, including high mechanical strength in the wet state, a high degree of crystallinity, biocompatibility, non-toxicity, high porosity, an ultrafine fiber network, selective permeability, and high water holding capacity (Pecoraro et al., 2008). Such features make BC an outstanding material suitable for technological applications in bioenergy, bioplastics, biomaterials, nanotechnology, biorefining, drug delivery, food, chemistry, packaging, paper, pharmaceuticals, medicine, oil recovery, textiles and wood (Chawla et al., 2009; Hoenich, 2007; Shah, 2013; Shi et al., 2014). Moreover, this cellulose has the advantage of being naturally free of lignin and hemicellulose (Chawla et al., 2009).

In the biomedical field, $\mathrm{BC}$ is primarily used for the development of burn dressings, vascular grafts, dental implant components, and drug delivery matrices and for the treatment of skin wounds (Henich, 2007). In 1980

\footnotetext{
* To whom correspondence should be addressed
} 
the Johnson \& Johnson Company initiated an intensive investigation of medical applications of $\mathrm{BC}$ as wound dressing. However, only in 2003, after the patents arising from this study were licensed to the Xylos Corporation, the XCell ${ }^{\circledR}$ product started to be manufactured and comercialized for the treatment of wounds (Sindhu et al, 2014). In Brazil, the main producer of cellulose membranes for treatment of wounds and skin burns is the company Bionext Biotechnological Products Ltd. (Donini et al, 2010). Besides Brazil, there are several companies in Canada, the United States and Japan, manufacturing e selling BC products for biomedical purposes (Sindhu et al, 2014).

$\mathrm{BC}$ applications are far beyond the biomedical field. 'Nata de Coco', a food product originally from the Philippines and consumed mainly in the production of desserts, became one of the first commercially available products from microbial cellulose, gaining remarkable popularity in Asian countries. Other food applications suggest the use of $\mathrm{BC}$ in processed foods to improve their quality, for example as low-calorie food additives, thickeners, stabilizers, texture modifiers, food packaging, etc. (Shi et al., 2014).

The excellent mechanical properties and high thermal stability of BC justify its use in papermaking. Indeed, companies such as Mitsubishi Paper Mills in Japan are investing many resources in the development of microbial cellulose for applications in paper products (Charreau et al. 2013). Other applications of this type of cellulose include its use in composites to obtain materials with specific properties, speaker membranes, aerogels, matrices to immobilize biomolecules or microorganisms, ultrafiltration membranes, and stabilizers for cosmetic emulsions ( Wu et al., 2013; Pecoraro et al., 2008; Chawla et al., 2009).

$\mathrm{BC}$ can be obtained through clean and low energy consumption processes by cultivating microorganisms, especially bacteria of the genus Komagataeibacter, in medium containing sugars and others nutrients. $\mathrm{BC}$ is obtained in a shorter time than that required for plant cellulose synthesis. Moreover, it does not require a large cultivation area, and it does not suffer from climate interferences or generate toxic effluent during the purification steps (Chawla et al., 2009). To reduce production costs, research projects have evaluated agroindustrial sources as alternative culture media for BC production. Examples of agro-industrial sources studied include: fruit juices (Jozala et al., 2015; Kurosumi et al., 2009), molasses (Çakar et al., 2014), molasses-corn steep liquor (Bae and Shoda, 2004; Jung et al., 2010), aqueous extract from grape skins, cheese whey, crude glycerol, sulfite pulping liquor (Jozala et al., 2015; Carreira et al., 2009), pineapple peel juice, sugar cane juice (Castro et al., 2011), coconut juice (Kongruang, 2008), waste beer yeast (Lin et al., 2014), maple syrup (Zeng et al., 2011), hydrolyzed starch, and coconut water (Hungund, 2013). In many cases, it is possible to achieve similar or superior production of $\mathrm{BC}$ when compared to methods using synthetic media. The use of alternative carbon sources in fermentation processes is important because this can reduce the environmental impact from the disposal of agro-industrial wastes, reduce the final cost of the product, and add value to the supply chains involved (Jozala et al., 2015).

In northeastern Brazil, the production of sisal stands out for its economic importance and for the amount of waste generated during its processing. Sisal (Agave sisalana) is a plant of Mexican origin introduced into Brazil in 1910. Since the 1930s, its cultivation is directed to the production of sisal fibers, which correspond to $70 \%$ of all production of hard fibers and generates around 80 million dollars per year in foreign exchange and half a million direct and indirect jobs. The world production of sisal in 2012 was 220 tons, with Brazil being the largest producer (40\%) (Branco et al., 2010; Faostat, 2015).

The sisal juice or sisal liquid corresponds to the whole liquid fraction obtained from discarded material during the processing of sisal fibers, and it is produced by pressing the sisal leaves. From the total weight of the processed leaves, a small amount $(\sim 4 \%)$ corresponds to the fiber, and the remaining residue is composed of a solid fraction $(\sim 16 \%)$ and a liquid fraction $(\sim 80 \%)$. The liquid fraction is composed of water $(\sim 85 \%)$, pigments, hecogenin, pectin, organic acids, minerals, proteins, and fermentable carbohydrates. Species of the genus Agave are known to produce large amounts of sugars; the sugar content in sisal juice can vary from 35 to $65 \mathrm{~g} / 1$ (Branco et al., 2010, Arrizon et al., 2010). There are no reports in the literature describing the industrial use of sisal juice. This residue is currently undervalued and discarded directly into the field. Thus, this study aimed at developing a process for the production of BC by Komagataeibacter hansenii ATCC 23769 , in static cultivation, using sisal juice as substrate.

\section{MATERIAL AND METHODS}

This article does not contain any studies with human participants or animals performed by any of the authors.

\section{Preparation and characterization of sisal juice}

Sisal juice was obtained using a technology developed by Embrapa Algodão. Sisal leaves were kindly given by CAMPOL, an agro-industrial cooperative located in Pocinhos - PB, Brazil. The juice samples were stored at $-18^{\circ} \mathrm{C}$ and thawed at the time of preparation of the culture medium.

All analytical determinations of pure sisal juice were performed on samples autoclaved at $121{ }^{\circ} \mathrm{C}$ for 15 minutes. $\mathrm{pH}$ was determined by potentiometry. Reducing and total sugars were determined by the DNS method 
(Miller, 1959), using glucose as standard. For total sugars determination, the DNS method was modified by preliminary acid hydrolysis $(2 \mathrm{~N} \mathrm{HCl})$ of the samples. Glucose, fructose and sucrose were determined by high performance liquid chromatography using a Varian PL HiPlex Ca $8 \mu \mathrm{m}$ column $(300 \times 7.7 \mathrm{~mm})$ maintained at $60{ }^{\circ} \mathrm{C}$ and equipped with a refractive index detector (Varian Pro Star $355 \mathrm{RI})$. The phenolic compounds were determined by spectroscopy using the Folin-Ciocalteu method with gallic acid as a standard (Roginsky and Lissi, 2005). The total nitrogen and protein content were determined by the Kjeldahl method (Yasuhara and Nokihara, 2001).

\section{Reagents and media components}

Bacteriological agar, casein peptone, and yeast extract powder were purchased from Himedia. D-Mannitol, ammonium sulfate, citric acid hydrate, anhydrous $d(+)-$ glucose, hydrogen peroxide, anhydrous sodium dihydrogen phosphate, and sodium hydroxide were purchased from Sigma-Aldrich.

\section{Microorganism and media preparation}

Komagataeibacter hansenii ATCC 23769 was obtained from the André Tosello Foundation. The strain was previously kept at $-18{ }^{\circ} \mathrm{C}$ in glycerol $20 \%(\mathrm{w} / \mathrm{v})$, was activated in mannitol broth $(5.0 \mathrm{~g} / \mathrm{L}$ of yeast extract; 3.0 $\mathrm{g} / \mathrm{L}$ of peptone, and $2.5 \mathrm{~g} / \mathrm{L}$ of D-mannitol), and statically cultured at $30{ }^{\circ} \mathrm{C}$ for 2 days. The culture was propagated by inoculation of $3 \%(\mathrm{v} / \mathrm{v})$ from mannitol broth to HS medium (Hestrin and Schramm, 1954) at $30{ }^{\circ} \mathrm{C}$ for $24 \mathrm{~h}$ and transferred to the evaluated culture medium.

The sisal juice media were filtered through a 20$\mu \mathrm{m}$ pore filter, diluted, the $\mathrm{pH}$ adjusted, supplemented (if necessary), and autoclaved at $121^{\circ} \mathrm{C}$ for 15 minutes. Following autoclaving, the media were aseptically filtered through a $20-\mu \mathrm{m}$ pore filter to remove any precipitates formed after sterilization.

\section{Evaluation of sisal juice as an alternative medium for BC production}

Some production conditions of $\mathrm{BC}$ in sisal juice by $G$. hansenii ATCC 23769 were studied to maximize cellulose production. The conventional optimization technique for fermentation parameters, the one-variable-at-a-time method, was applied. Assays were realized in Petri dishes of $14.5 \mathrm{~cm}$ diameter containing $100 \mathrm{~mL}$ of inoculated medium per dish $(3 \%$ of inoculum, $\mathrm{v} / \mathrm{v})$. The culture plates were incubated at $30{ }^{\circ} \mathrm{C}$ under static conditions. The yield of cellulose production in the alternative media was compared with the yield obtained in synthetic HS medium.

\section{Effect of dilution}

$\mathrm{BC}$ production was evaluated in different dilutions of sisal juice, with initial sugar concentrations ranging from 2.5 to $15 \mathrm{~g} / \mathrm{L}$. The initial $\mathrm{pH}$ of the medium was adjusted to $\mathrm{pH} 5.0$ and $\mathrm{BC}$ production in different dilutions was evaluated after 5 days of cultivation.

\section{Effect of initial $p H$}

The effect of initial $\mathrm{pH}$ (pH 3.0 to 8.0) on $\mathrm{BC}$ production was studied using culture medium containing sisal juice with a sugar concentration of $15 \mathrm{~g} / \mathrm{L}$.

\section{Effect of nitrogen supplementation}

The effect of medium supplementation with nitrogen sources (yeast extract and/or ammonium sulfate) on $\mathrm{BC}$ mass (M) production was evaluated using a Central Composite Rotational Design (CCDR) with $2^{2}$ factorial and a central and axial point. The concentrations ranged from 0 to $15 \mathrm{~g} / \mathrm{L}$ for yeast extract and 0 to $10 \mathrm{~g} / 1$ for ammonium sulfate. The production of BC on a dry basis $(\mathrm{g} / \mathrm{L})$ and yield $\left(\mathrm{Y}_{\mathrm{P} / \mathrm{S}}, \%\right)$ were defined as response variables. Cultivation time was 5 days, with initial $\mathrm{pH} 5.0$ and initial sugar concentration of $15 \mathrm{~g} / \mathrm{L}$.

\section{Effect of culture time}

After selecting the best conditions for $\mathrm{BC}$ production in sisal juice, $\mathrm{BC}$ production was evaluated for up to 22 days in HS medium (HS), selected sisal medium (SI), and labmade synthetic medium (SM) (Table 1). The SM medium contained glucose, fructose, and sucrose as carbon sources, and peptone and yeast extract as nitrogen sources. The carbon/nitrogen $(\mathrm{C} / \mathrm{N})$ ratio of SM was similar to that of SI.

\section{Analysis of fermentation media and quantification of $B C$ production}

After fermentation, the $\mathrm{BC}$ pellicles were harvested and the fermented media subjected to analysis of $\mathrm{pH}$ and total sugars by the DNS method (Miller, 1959). Before the sugar content was analyzed, the media were filtered through 0.2 $\mu \mathrm{m}$ pore membranes to remove any microbial cells.

$\mathrm{BC}$ pellicles were purified by alkali treatment prior to determination of dry weight. Impure pellicles were washed with water, following immersion in a $1 \mathrm{~N} \mathrm{NaOH}+1 \%$ $\mathrm{H}_{2} \mathrm{O}_{2}(\mathrm{v} / \mathrm{v})$ solution $(100 \mathrm{~mL}$ of solution/pellicle) at 80 ${ }^{\circ} \mathrm{C}$ for one hour. After alkali treatment, the pellicles were rinsed in distilled water until a neutral $\mathrm{pH}$ was obtained.

BC dry mass was determined by weighing the dry, purified membranes using an infrared balance $\left(170{ }^{\circ} \mathrm{C}\right)$. The yield $\left(\mathrm{Y}_{\mathrm{P} / \mathrm{S},}\right.$ \%) was estimated according to Eq. (1):

$$
\mathrm{Y}_{\mathrm{P} / \mathrm{S}}=\left(m B C /\left(S_{i}-S_{f}\right)\right) \times 100
$$


Table 1. Composition of culture media for BC production.

\begin{tabular}{|c|c|c|c|}
\hline Compounds $\left(\mathrm{g} \cdot \mathrm{L}^{-1}\right)$ & SI & SM & HS \\
\hline Total Sugar & 15 & 15 & 20 \\
\hline Glucose & $12.35^{\mathrm{a}}$ & 12.35 & 20 \\
\hline Sucrose & $1.49^{\mathrm{a}}$ & 1.49 & 0 \\
\hline Fructose & $1.17^{\mathrm{a}}$ & 1.17 & 0 \\
\hline Casein peptone & 0 & 7.43 & 5 \\
\hline Total protein ${ }^{\mathrm{b}}$ & 11.34 & 14.93 & 10 \\
\hline Yeast extract & 7.5 & 7.5 & 5 \\
\hline Proteins from sisal juice & $3.84^{\mathrm{a}}$ & 0 & 0 \\
\hline Citric acid & 0 & 0 & 1.15 \\
\hline Sodium phosphate & 0 & 0 & 2.75 \\
\hline
\end{tabular}

${ }^{a}$ Levels of naturally derived sisal juice.

${ }^{\mathrm{b}}$ Total protein was defined as the sum of proteins from sisal juice, casein peptone, and yeast extract.

$\mathrm{mBC}$ is the dry mass of $\mathrm{BC}$ produced per liter of medium, $\mathrm{S}_{\mathrm{i}}$ is the initial sugar concentration $(\mathrm{g} / \mathrm{L})$ and $\mathrm{S}_{\mathrm{f}}$ is the final sugar concentration $(\mathrm{g} / \mathrm{L})$ in the fermentation broth.

\section{Statistical analyses}

Results for the Central Composite Rotational Design were analysed using a mixed model analysis of variance (ANOVA) with 90\% confidence intervals (Tukey's test). The other results were analyzed using ANOVA with $95 \%$ of confidence interval.

\section{Infrared Analysis (FTIR)}

To evaluate the efficiency of the purification process the BC samples were examined using a Fourier transform infrared spectrometer (FTIR, Nicolet 800 combined with a MTech PAS cell). Spectra were obtained between 4000 and $400 \mathrm{~cm}^{-1}$ at a $4 \mathrm{~cm}^{-1}$ resolution, using an ATR crystal module with zinc selenide.

\section{Scanning Electron Microscopy (SEM)}

BC films were frozen at $-80{ }^{\circ} \mathrm{C}$ for 24 hours and freeze-dried for 72 hours. The pellicles were metalized by platinum sputtering and analysed by scanning electron microscopy (SEM) on a Zeiss DSM-940A microscope at $30 \mathrm{keV}$. The diameter of 50 nanofibers was determined using the ImageJ program (National Institute of Health$\mathrm{NIH})$.

\section{RESULTS AND DISCUSSION}

\section{Sisal juice characterization}

Sisal juice used in this study had a pH of $4.48 \pm 0.01$ and contained nitrogen $(0.62 \mathrm{~g} / \mathrm{L})$, phenolic compounds $(1.73$ $\mathrm{g} / \mathrm{L})$, and sugars $(15.05 \mathrm{~g} / \mathrm{L}$ corresponding to $82 \%$ glucose,
$10 \%$ sucrose, and $8 \%$ fructose), thus being a nitrogen and carbon source for the fermentation process.

Sisal juice can be considered as a potential substrate for production of $\mathrm{BC}$ because the producing bacteria from Komagataeibacter generally require a source of sugars and nitrogen to be present in the medium (Jozala et al., 2015; Kurosumi et al., 2009; Çoban and Biyik, 2011). Media with sugar levels ranging from 10 to $20 \mathrm{~g} / \mathrm{L}$ may provide an optimal condition for $\mathrm{BC}$ production, as demonstrated in different studies (Jung et al., 2010; Keshk and Sameshima, 2006; Jung et al., 2005).

\section{Effect of dilution}

Strain G. hansenii ATCC 23769 was able to synthesize cellulose throughout the whole range of sugar concentrations tested $(2.5$ to $15 \mathrm{~g} / \mathrm{L})$. The highest production of $\mathrm{BC}(2.6$ $\mathrm{g} / \mathrm{L}$ ) was observed without dilution, at $15 \mathrm{~g} / \mathrm{L}$ of sugar (Fig. 1a). Even with the gradual increase in cellulose production, the yield remained statistically constant (around 25\%) at all concentrations. The production of $\mathrm{BC}$ and the yields were almost 3-fold higher in sisal medium than in standard synthetic HS medium (Table 2). The BC pellicles obtained after fermentation in HS and sisal media are shown in Figure 2, and the fermentation conditions are described in Table 2.

Both pellicles were visually similar, although the sisal-fermented pellicle was less transparent because of its higher cellulose mass. Final $\mathrm{pH}$ values in HS and sisal media were around 3.5 and 8.3 , respectively.

The FTIR spectra of purified BC samples produced in SM and HS media followed the characteristic profile reported in the literature (Gea et al., 2011). Several relevant bands characteristic of cellulose were found, many of them related to $\mathrm{OH}$ and $\mathrm{CH}$ bonds. The pellicle purification was effective, since no additional bands, related to nitrogen, protein structures, or possible contaminants $(1535,1730$ 1735,3150 to 3220 ) were detected (Data not shown). 
Table 2. Production of cellulose by Komagataeibacter hansenii ATCC 23769 in synthetic medium (HS) and in sisal juice.

\begin{tabular}{ccccccc}
\hline Medium & $\begin{array}{c}\text { Initial Sugar } \\
\left(\mathrm{g} \cdot \mathrm{L}^{-1}\right)\end{array}$ & $\begin{array}{c}\text { Initial Nitrogen } \\
\left(\mathrm{g} \cdot \mathrm{L}^{-1}\right)\end{array}$ & $\begin{array}{c}\mathrm{BC} \\
\text { production }\left(\mathrm{g} \cdot \mathrm{L}^{-1}\right)\end{array}$ & $\begin{array}{c}\mathrm{Y}_{\mathrm{P} / \mathrm{S}} \\
(\%)\end{array}$ & $\begin{array}{c}\text { Final Sugar } \\
\left(\mathrm{g} \cdot \mathrm{L}^{-1}\right)\end{array}$ & $\begin{array}{c}\text { Final } \\
\mathrm{pH}\end{array}$ \\
\hline Sisal juice & 15 & 0.62 & $2.60 \pm 0.19^{\mathrm{a}}$ & $25.45 \pm 0.19^{\mathrm{a}}$ & $10.24 \pm 0.65^{\mathrm{a}}$ & $8.35 \pm 0.22^{\mathrm{a}}$ \\
HS & 20 & 1.25 & $0.90 \pm 0.13^{\mathrm{b}}$ & $11.82 \pm 1.04^{\mathrm{b}}$ & $12.39 \pm 0.30^{\mathrm{a}}$ & $3.48 \pm 0.1^{\mathrm{b}}$ \\
\hline
\end{tabular}

Same letters in the column are not significantly different $(\alpha=0.05)$.

a

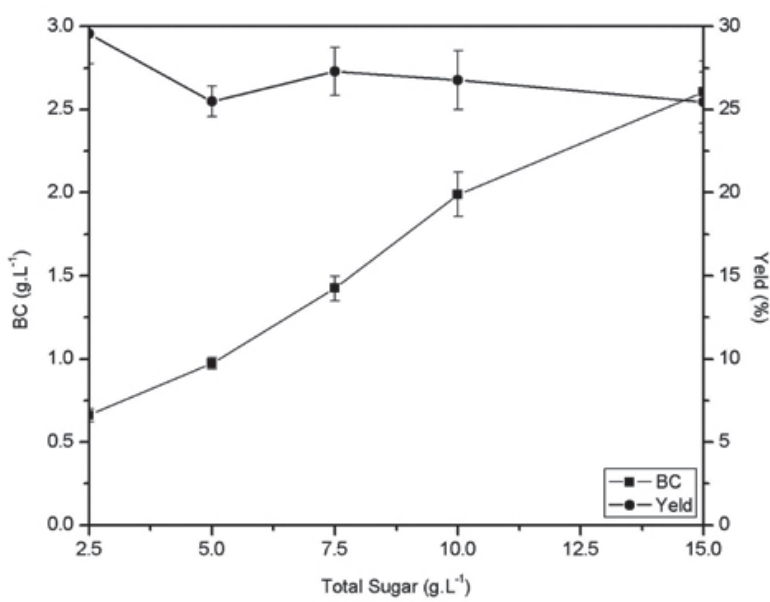

b

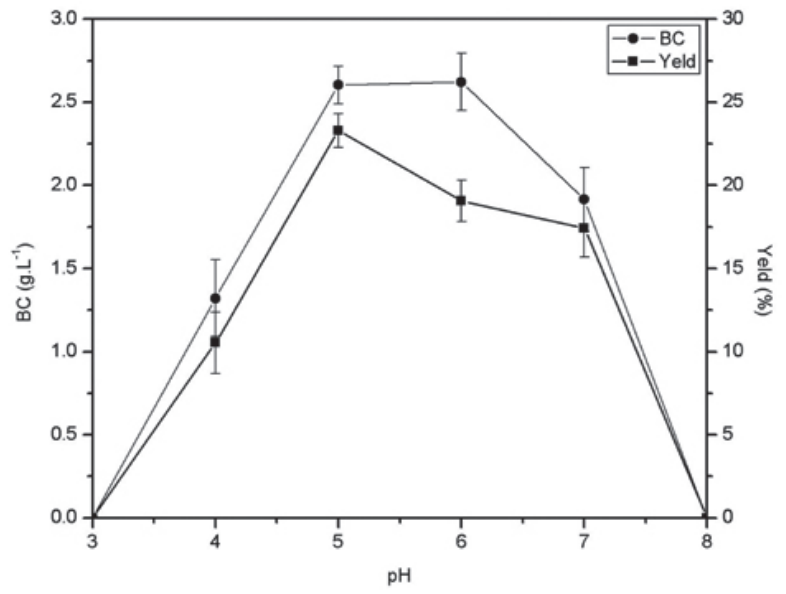

Figure 1. Effect of sisal juice dilution (a) and initial fermentation $\mathrm{pH}$ (b) on bacterial cellulose production by Komagataeibacter hansenii ATCC 23769 using sisal juice as substrate
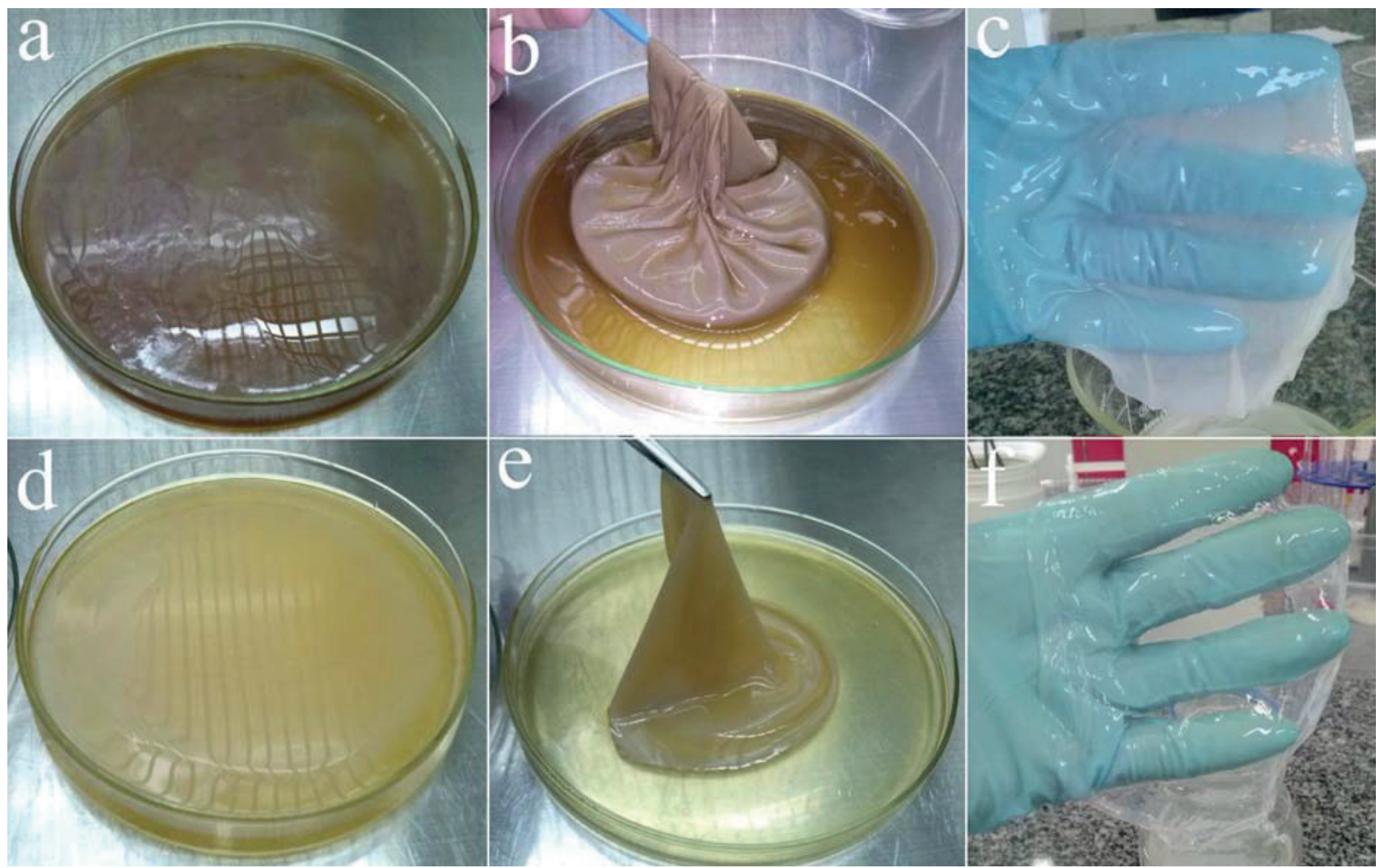

Figure 2. Bacterial cellulose pellicles obtained from sisal juice medium (a, b and c) and HS medium (d, e and f). Pellicles on the surface of the medium after 5 days of culture (a and d), pellicles being removed ( $b$ and e), and purified pellicles in the wet state (c and $f$ ) 
In this research, the amount of $\mathrm{BC}$ produced increased linearly $\left(\mathrm{R}^{2}=0.9886\right)$ as the initial sugar content increased. However, as the maximum amount of sugar found in pure sisal juice was $15 \mathrm{~g} / \mathrm{L}$, it was not possible to test higher concentrations. The increment of cellulose production with an increase in initial sugar concentration was significant (up to $394 \%$ from 2.5 to $15 \mathrm{~g} / \mathrm{L}$ of initial sugar). $\mathrm{BC}$ production in media containing 10 to $40 \mathrm{~g} / \mathrm{L}$ of glucose ranged between 1.21 to $1.51 \mathrm{~g} / \mathrm{L}$, which was not considered to be a significant increase (Jung et al., 2010). The increase of sugar concentration from 5 to 15 $\mathrm{g} / \mathrm{L}$ during cultivation of Acetobacter sp. HS V6 in HS medium resulted in a gradual increase in $\mathrm{BC}$ production, but the production decreased with sugar concentrations higher than $20 \mathrm{~g} / \mathrm{L}$ (Santos et al., 2012). The highest levels of production of $\mathrm{BC}$ achieved during cultivation of Komagataeibacter xylinus ATCC 10245 in HS medium were obtained at a sugar concentration of $10 \mathrm{~g} / \mathrm{L}$, while higher sugar concentrations (20 and $30 \mathrm{~g} / \mathrm{L}$ ) decreased the production (Keshk and Sameshima, 2006). In another research, the highest $\mathrm{BC}$ production $(5.3 \mathrm{~g} / \mathrm{L})$ was reached after Acetobacter xylinum BPR 2001 culture in sugar cane molasses with a sugar concentration adjusted to $20 \mathrm{~g} / \mathrm{L}$. At higher sugar concentrations (50 and $70 \mathrm{~g} / \mathrm{l}$ ), the production decreased (Bae and Shoda, 2004).

Also, the addition of antioxidant compounds in the fermentative medium favored the production of $\mathrm{BC}$ because the antioxidants inhibit the formation of gluconic acid (Jozala et al., 2015; Keshk and Sameshima, 2006). Species from the genus Agave are sources of antioxidant compounds with inhibitory activity against oxidative enzymes (Santos et al., 2012), while bacteria from the genus Komagataeibacter can metabolize tannins, which accounts for their resilience and development in agroindustrial media (Usha and Appaiah, 2012). Thus, the antioxidant phenolic compounds naturally present in sisal juice may have contributed to the inhibition of organic acid accumulation in the broth, thereby increasing $\mathrm{BC}$ production.

\section{Effect of initial pH}

$\mathrm{BC}$ production and yield at different initial $\mathrm{pH}$ values are shown in Figure 1b. The highest BC production was observed at $\mathrm{pH} 5$ and $6(2.60 \mathrm{~g} / \mathrm{l})$ and the highest yield was observed at pH 5 (23.29\%). Even with similar production levels, the sugar consumption at $\mathrm{pH} 6$ was $24 \%$ higher than at $\mathrm{pH} 5$. There was no production of $\mathrm{BC}$ and no consumption of the substrate by the microorganism at $\mathrm{pH}$ 3 , indicating that this condition inhibited bacteria growth. There was no $\mathrm{BC}$ production at $\mathrm{pH} 8$, although more than $92 \%$ of the sugar supplied was consumed, possibly through an alternate metabolic pathway. Similar results have been described in other studies (Chawla et al., 2009; Hoenich, 2007; Hestrin and Schramm, 1954), therefore allowing us to conclude that the best $\mathrm{BC}$ production occurs within the $\mathrm{pH}$ range between 5 and 6 .

Production of $\mathrm{BC}$ from glucose rich media leads to the production and accumulation of organic acids in the broth, and this in turn leads to a decrease in $\mathrm{pH}$, shifting from the ideal $\mathrm{pH}$ range between 5.0 and 6.0, and inhibiting the cellulose production after a certain cultivation period (Chawla et al., 2009; Jung et al., 2010; Kongruang, 2008; Hestrin and Schramm, 1954). This explains the low BC production when $\mathrm{pH}$ below 5 was used in this work.

\section{Effect of nitrogen supplementation}

The mass of $\mathrm{BC}(\mathrm{M})$ and yield $\left(\mathrm{Y}_{\mathrm{P} / \mathrm{S}}\right)$ ranged from $1.76 \mathrm{~g} / \mathrm{L}$ to $3.38 \mathrm{~g} / \mathrm{L}$, and $15.56 \%$ to $25.16 \%$, respectively (Table 3 ). The difference between the maximum and the minimum points is much larger than the variation conditions of the central point, where the reproducibility of the experiment is evaluated ( $\Delta=0.46$ and 3.49 , for $\mathrm{M}$ and $\mathrm{Y}_{\mathrm{P} / \mathrm{S}}$, respectively), indicating that the variations observed for different planning assays are derived from different culture conditions.

For the response variable $\mathrm{M}(\mathrm{g} / \mathrm{l})$, only the linear effects of each variable were significant $(\alpha=0.1)$; the effect of ammonium sulfate supplementation was negative, while the effect of yeast extract supplementation was positive. For the response variable $\mathrm{Y}_{\mathrm{P} / \mathrm{S}}$ no effect was significant.

Table 3. Influence of supplementary nitrogen sources on production and yield of bacterial cellulose by Komagataeibacter hansenii ATCC 23769 using sisal juice as substrate. Central composite experimental design $2^{2}$.

\begin{tabular}{ccccc}
\hline Assay & Yeast extract $\left(\mathrm{g} \cdot \mathrm{L}^{-1}\right)$ & $\mathrm{NH}_{4} \mathrm{SO}_{2}\left(\mathrm{~g} \cdot \mathrm{L}^{-1}\right)$ & $\mathrm{M}\left(\mathrm{g} \cdot \mathrm{L}^{-1}\right)$ & $\mathrm{Y}_{\mathrm{P} / \mathrm{S}}(\%)$ \\
\hline 1 & $2.2(-1)$ & $1.5(-1)$ & 2.92 & 2.31 \\
2 & $2.2(-1)$ & $8.5(+1)$ & 3.01 & 23.30 \\
3 & $12.8(+1)$ & $1.5(-1)$ & 2.48 & 22.20 \\
4 & $12.8(+1)$ & $8.5(+1)$ & 1.76 & 18.17 \\
5 & $0(-1.44)$ & $5(0)$ & 2.83 & 12.60 \\
6 & $15(+1.44)$ & $5(0)$ & 3.38 & 22.62 \\
7 & $7.5(0)$ & $0(-1.44)$ & 2.14 & 25.16 \\
8 & $7.5(0)$ & $10(+1.44)$ & 2.69 & 15.56 \\
9 & $7.5(0)$ & $5(0)$ & 2.50 & 20.20 \\
10 & $7.5(0)$ & $5(0)$ & 2.96 & 18.73 \\
11 & $7.5(0)$ & $5(0)$ & & 22.22 \\
\hline
\end{tabular}


Analyzing separately each experiment, the highest production $\left(3.38 \mathrm{~g} \cdot \mathrm{L}^{-1}\right)$ and yield $(25.16 \%)$ were obtained in assay 7 , where the medium was supplemented with 7.5 $\mathrm{g} / \mathrm{l}$ of yeast extract. This production was higher than that in unsupplemented medium (2.6 g/l) (Table 2), representing a gain of $30 \%$ in production.

Media supplementation with nitrogen sources for BC production has been discussed in the literature by many authors. A higher BC production in a medium containing glucose was obtained when the medium was supplemented with yeast extract instead of ammonium sulfate (Çoban and Biyik, 2011). Yeast extract and peptone are the most suitable nitrogen sources for $\mathrm{BC}$ production. The addition of such organic sources is indispensable for a significant production (Kurosumi et al., 2009; Jung et al., 2010). The negative effect of ammonium sulfate addition in this work indicates that inorganic sources of nitrogen can exert an inhibitory effect on the metabolism of BCproducing bacteria, as observed in the literature (Panesar et al., 2012). Furthermore, the addition of a nitrogen source

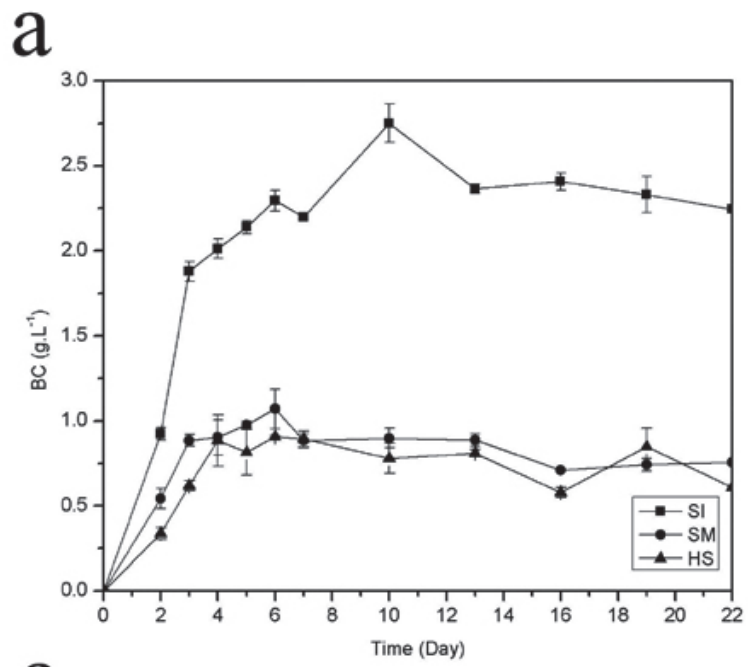

C

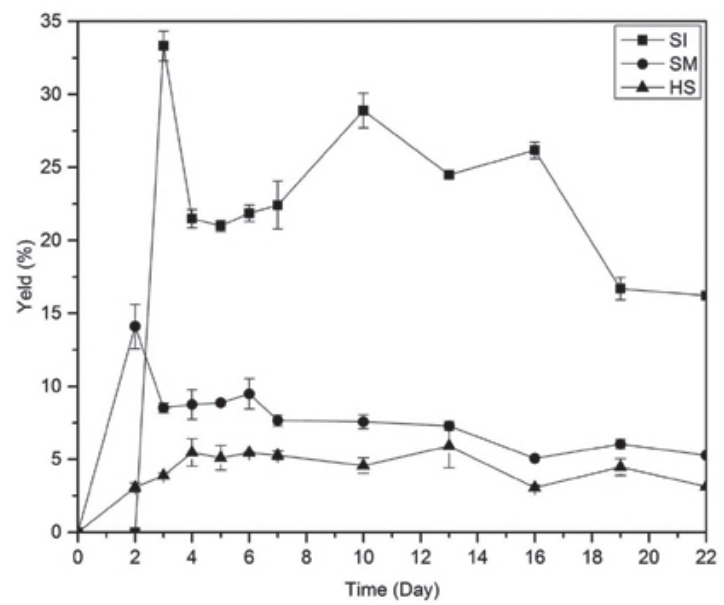

above the limit promotes biomass increase and reduces BC production (Panesar et al., 2012).

\section{Effect of cultivation time}

Figure 3 shows the results of sugar consumption, yield, and $\mathrm{pH}$ during 22 days of culture in the media tested. In all tested media, the cellulose production increased over time (Fig. 3a) as sugar content decreased (Fig. 3b), indicating the relationship between substrate consumption and product formation. BC production stabilized after the $10^{\text {th }}$ day in SI medium and after the $4^{\text {th }}$ day in SM and HS media. Maximum BC production was obtained in SI medium (2.75 g/l) (Fig. 3a).

The $\mathrm{pH}$ of the SM and HS media decreased with time due to production and accumulation of organic acids in the broth, as previously stated. However, the $\mathrm{pH}$ of SI medium increased to 8.3. In all media, the $\mathrm{pH}$ stabilized after the $4^{\text {th }}$ day of culture (Fig. 3d).

Yield reached a maximum value of $33.3 \%$ on the $3^{\text {th }}$ day
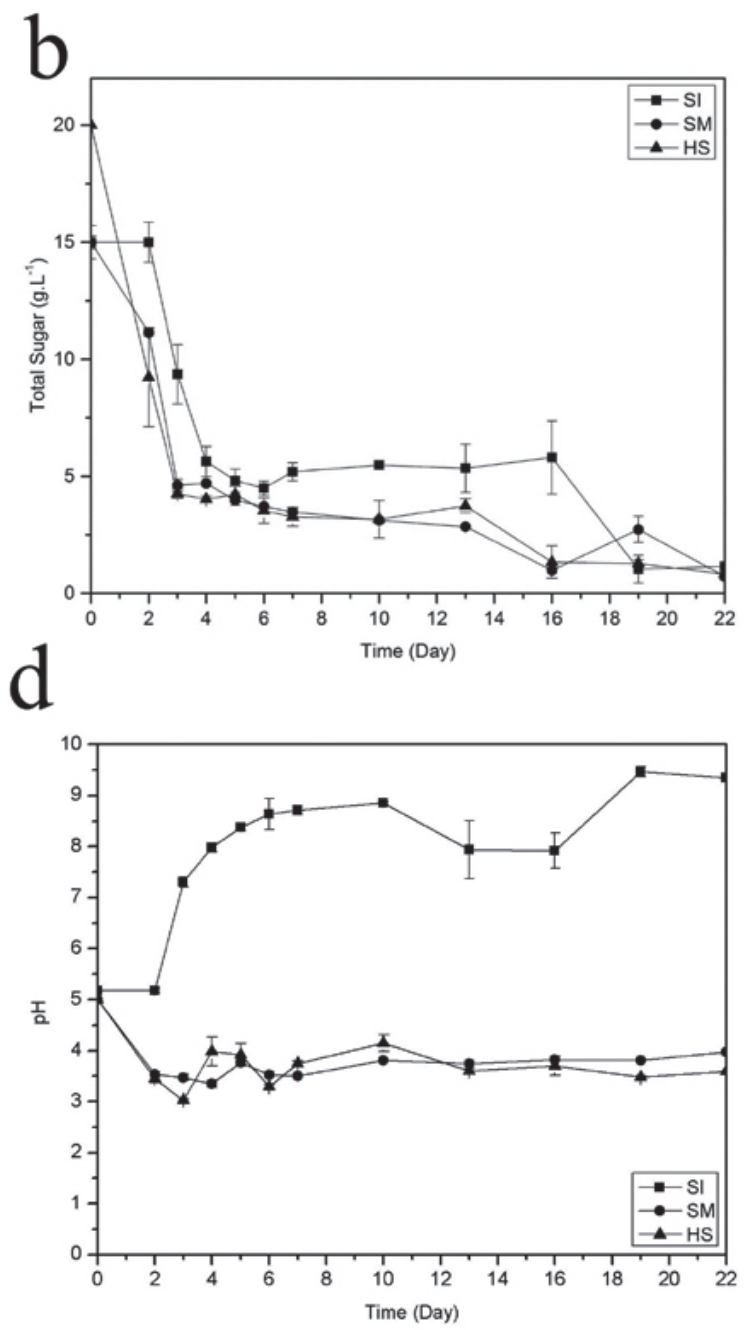

Fig. 3 Bacterial cellulose production parameters: BC production (a), sugar consumption (b), yield (c), and pH variation (d) during 22 days of culture in sisal juice medium (SI), synthetic medium (SM), and HS medium (HS). 
in SI culture, with a gradual decrease in the following days (Figure $3 \mathrm{C}$ ). SM and HS cultures presented maximum yield of $14.1 \%$ on the second day and $5.4 \%$ on the $4^{\text {th }}$ day, respectively. In all cases, there was a higher sugar consumption and $\mathrm{BC}$ production in the first 72 hours of culture. SI fermentative medium increased the $\mathrm{BC}$ yield by around 2.3 -fold in comparison to the SM and by around 5.6-fold in comparison to the HS.

According to the literature, the $\mathrm{BC}$ production and yields may vary depending on the sugar source used and the conditions of the fermentation process (Jozala et al., 2015 ). Yield decreased from $66 \%$ to $30 \%$ from the $2^{\text {nd }}$ to the $4^{\text {th }}$ day of culture of G. xylinus ATCC 53524 in HS and the most significant increase happened in the first 4 days of culture. BC production by G. xylinus ATCC 53524 in HS medium ranged from 1.89 to $3.10 \mathrm{~g} / \mathrm{l}$ between the second and fourth day of cultivation (Mikkelsen et al., 2009). It was similar to that obtained for $G$. hansenii ATCC 23769 in SM and HS medium in this work. For Gluconacetobacter sp. RKY5 in HS medium, there was no increase in $\mathrm{BC}$ production after 6 days of culture (Young, 2011). In others works, $B C$ production stabilized at longer times of cultivation (Son et al., 2003; Jung et al., 2010), as observed for G. hansenii ATCC 23769 in SI medium. The results indicate that $\mathrm{pH}$ variations tend to stabilize when cellulose production ends and the sugar consumption is not significant. The bio-compounds naturally present in sisal juice, such as phenolics, probably contributed to the increased conversion of sugars to $\mathrm{BC}$ when sisal juice is compared with the two synthetic media studied (SM and HS).

\section{SEM}

The SEM images confirmed the characteristic threedimensional BC structure (data not shown). Moreover, there were no significant differences between the membranes from different media and the fibril diameters were below $100 \mathrm{~nm}$ in HS $(80.39 \pm 23.03 \mathrm{~nm})$ and SI $(73.86 \pm 16.20$ $\mathrm{nm})$ fermentative media.

Different culture media can influence the BC morphology (Jozala et al., 2015). In spite of the quantitative differences in the evaluated media, SEM pictures of BC from both cultures are qualitatively similar. This similarity indicates that $\mathrm{BC}$ from sisal juice medium may be used for the same applications as $\mathrm{BC}$ produced in the standard synthetic medium.

\section{CONCLUSION}

According to the results presented, a process for $\mathrm{BC}$ production using sisal juice as substrate was developed. Sisal juice promoted significant gains in mass and yield compared to HS medium, with no significant difference in the nanofiber diameter. The maximum levels of $\mathrm{BC}$ production by G. hansenii ATCC 23769 were achieved through the static cultivation of the bacteria for 10 days, using sisal juice containing $15 \mathrm{~g} / \mathrm{L}$ of sugars, supplemented with $7.5 \mathrm{~g} / \mathrm{L}$ of yeast extract, at an initial $\mathrm{pH}$ of 5 . Furthermore, the fermentative process developed with sisal juice was effective and better than in HS medium. Probably, sisal secondary metabolites improved the $\mathrm{BC}$ production, affecting the $G$. hansenii metabolic pathways. Comparing the productivity reached in this work with the literature, it could be seen that Komagataeibacter hansenii ATCC 23769 is not the most effective BC producer. However, the results clearly showed that sisal juice has potential as an alternative culture medium. In fact, the BC production was around 3-fold higher than in HS medium. This adds value to the sisal wastes and improves $\mathrm{BC}$ production, contributing to solve issues of up-scaling of $\mathrm{BC}$ production and the use of agroindustrial wastes.

\section{ACKNOWLEDGMENTS}

The research that led to this article was funded by the Brazilian research funding agencies National Counsel of Technological and Scientific Development (CNPq), Coordination for the Improvement of Higher Education Personnel (CAPES) and, Ceara State Research Foundation (FUNCAP). The authors also thank CAMPOL (Cooperativa Agropecuária Mista de Pocinhos Ltda).

\section{NOMENCLATURE}

\section{Abbreviations}

$\mathrm{BC}$ - Bacterial cellulose

CCRD - Central composite rotational design

CAMPOL - Cooperativa Agropecuária Mista de Pocinhos Ltda

PB - Paraíba (Brazil State)

HS - Hestrin and Scharman medium

SI - Selected sisal Medium

SM - Lab-made synthetic medium

$\mathrm{C} / \mathrm{N}-$ Carbon/Nitrogen ratio

DNS - 3,5-dinitrosalicylic acid colorimetric method

ANOVA - Analysis of variance

SEM - Scanning electron microscopy

CNPq - National Counsel of Technological and Scientific

Development

CAPES - Coordination for the Improvement of Higher

Education Personnel

FUNCAP - Ceara State Research Foundation

Symbols

$\mathrm{M}$ - Bacterial cellulose mass

$\mathrm{Y}_{\mathrm{P} / \mathrm{S}}-$ Yield (\%)

$\mathrm{mCB}$ - Dry mass of bacterial cellulose produced $(\mathrm{g} / \mathrm{L})$

$\mathrm{S}_{\mathrm{i}}$ - Inicial sugar concentration $(\mathrm{g} / \mathrm{L})$

$\mathrm{S}_{\mathrm{f}}$ - Final sugar concentration $(\mathrm{g} / \mathrm{L})$ 
$\mathrm{R}^{2}$ - Coefficient of determination

$\Delta$ - Variation of central point

$\alpha$ - Significance level

\section{REFERENCES}

Arrizon J., Morel S., Gschaedler A. and Monsan P., Comparison of the water-soluble carbohydrate composition and fructan structures of Agave tequilana plants of different ages, Food Chemistry, 122, No. 1, 123 (2010).

Bae S. and Shoda M., Bacterial cellulose production by fed-batch fermentation in molasses medium, Biotechnology Progress, 20, No. 5, 1366 (2004).

Branco A., Santos J.D.G., Pimentel M.M.A.M., Osuna J.T.A., Lima L.S. and David J.M., d-Mannitol from Agave sisalana biomass waste, Industrial Crops and Products, 32, No. 3, 507 (2010).

Brown A.J., On an acetic ferment which forms cellulose, Journal of the Chemical Society, Transactions, 49, 432 (1886).

Çakar F., Ozer I., Aytekin A.Ö. and Sahin F., Improvement production of bacterial cellulose by semi-continuous process in molasses medium, Carbohydrate Polymers, 106, No. 15, 7 (2014).

Carreira P., Mendes J.A.S., Trovatti E., Serafim L.S., Freire C.S.R., Silvestre A.J.D. and Neto C.P., Utilization of residues from agro-forest industries in the production of high value bacterial cellulose, Bioresource Technology, 102, No. 15, 7354 (2011).

Castro C., Zuluaga R., Putaux J.L., Caroa G., Mondragond I. and Gañán P., Structural characterization of bacterial cellulose produced by Gluconacetobacter swingsii sp. from Colombian agroindustrial wastes, Carbohydrate Polymers, 84, No. 1, 96 (2011).

Charreau H., Foresti M.L. and Vazquez A., Nanocellulose Patents Trends: A Comprehensive Review on Patents on Cellulose Nanocrystals, Microfibrillated and Bacterial Cellulose, Recent Patents on Nanotechnology, 7, No. 1, 56 (2013).

Chawla P.R., Bajaj I.B., Survase S.A. and Singhal R.S., Microbial Cellulose: Fermentative Production and Applications, Food Technology and Biotechnology, 47, No. 2, 107 (2009).

Çoban E.P. and Biyik H., Effect of various carbon and nitrogen sources on cellulose synthesis by Acetobacter lovaniensis HBB5, African Journal of Biotechnology, 10, No. 27, 5346 (2011).

Donini I.A.N., DE Salvi D.T.B., Fukumoto F.K., Lustri W.R., Barud H.S., Marchetoo R., Messaddeq Y. and Ribeiro S.J.L., Biosynthesis and recent advances in production of bacterial cellulose, Eclética Química, 35, No. 4, 165 (2010).

Faostat, Food and Agriculture Organization of the United Nations, Statistics Division. http://faostat3faoorg/browse/Q/ QC/E. Accessed 13 August (2015).

Gea, S., Reynolds, C.T., Roohpour, N., Wirjosentono, B., Soykeabkaew, N., Bilotti, E., and Peijs, T., Investigation into the structural, morphological, mechanical and thermal behaviour of bacterial cellulose after a two-step purification process, Bioresource technology, 102, No. 19, 9105 (2011).

Hestrin S. and Schramm M., Synthesis of cellulose by Acetobacter xylinum Preparation of freeze-dried cells capable of polymerizing glucose to cellulose, Biochemical Journal. 58, No. 2, 345 (1954).

Hoenich N.A., Cellulose for medical applications: past, present, and future, BioResources, 1, No. 2, 270 (2007).

Hungund B., Production of bacterial cellulose from Gluconacetobacter persimmonis $\mathrm{GH}-2$ using dual and cheaper carbon sources, Journal of Microbial \& Biochemical Technology 5, No. 2, 31 (2013).

Jozala A.F., Pértile R.A.N., Santos C.A., Santos E.V.C., Seckler M.M., Gama, F.M. and Pessoa J.A., Bacterial cellulose production by Gluconacetobacter xylinus by employing alternative culture media, Applied microbiology and biotechnology, 99, No. 13, 1181 (2015).

Jung H.I., Lee O.M., Jeong J.H., Jeon Y.D., Park K.H., Kim H.S., An W.G. and Son H.J., Production and characterization of cellulose by acetobacter sp. V6 using a cost-effective molasses-corn steep liquor medium, Applied Biochemistry and Biotechnology, 162, No. 2, 486 (2010).

Jung J.Y., Park J.K. and Chang H.N., Bacterial cellulose production by Gluconacetobacter hansenii in an agitated culture without living non-cellulose producing cells, Bacterial cellulose production by Gluconacetobacter hansenii in an agitated culture without living non-cellulose producing cells, 37, No. 3, 347 (2005).

Keshk S. and Sameshima K., Influence of lignosulfonate on crystal structure and productivity of bacterial cellulose in a static culture, Enzyme and Microbial Technology, 40, No. 1, 4 (2006).

Kongruang S., Bacterial cellulose production by Acetobacter xylinum strains from agricultural waste products, Appl Biochem Biotechnology, 148, No. 1-3, 245 (2008).

Kurosumi A., Sasaki C., Yamashita Y. and Nakamura Y., Utilization of various fruit juices as carbon source for production of bacterial cellulose by Acetobacter xylinum NBRC 13693, Carbohydrate Polymers, 76, No. 2, 333 (2009).

Lin D., Lopez S.P., Li R. and Li Z., Production of bacterial cellulose by Gluconacetobacter hansenii CGMCC 3917 using only waste beer yeast as nutrient source, Bioresource Technology, 151, 113 (2014).

Mikkelsen D., Flanagan B.M., Dykes G.A. and Gidley M.J., Influence of different carbon sources on bacterial cellulose production by Gluconacetobacter xylinus strain ATCC 53524, Journal of Applied Microbiology, 107, No. 2, 576 (2009).

Miller G.L., Use of Dinitrosalicylic Acid Reagent for Determination of Reducing Sugar. Analitycal Chemistry, 31, No. 3, 426 (1959)

Panesar P.S., Chavan Y., Chopra H.K. and Kennedy J.F., Production of microbial cellulose: Response surface methodology approach, Carbohydrate Polymers. 87, No. 1, 930 (2012).

Pecoraro É., Manzani D., Messaddeq Y. and Ribeiro S.J.L., Monomers, polymers and composites from renewable resources, Bacterial Cellulose from Glucanacetobacter xylinus: Preparation, Properties and Applications. 1st edn. Elsevier, Amsterdam (2008).

Roginsky V. and Lissi E., Review of methods to determine chainbreaking antioxidant activity in food, Food Chemistry, 92, No. 2, 235 (2005). 
Santos J.D.G, Espeleta A.F., Branco A. and Assis S.A., Aqueous extraction of pectin from sisal waste, Carbohydrate Polymers, 92, No. 2, 1997 (2013).

Santos Z.L., Leal D.A., Cortes C.E. and Gutierrez U.J., Agave (Agave spp.) and its Traditional Products as a Source of Bioactive Compounds, Current Bioactive Compounds, 8, No. 3, 218 (2012).

Shah N., Ul-Islam M., Khattak W.A. and Park J.K., Overview of bacterial cellulose composites: a multipurpose advanced material, Carbohydrate Polymers, 98, No. 2, 1585 (2013).

Shi Z., Zhang Y., Phillips G.O. and Yang G., Utilization of bacterial cellulose in food, Food Hydrocolloids, 35, 539 (2014).

Sindhu K.A., Prasanth R. and Thakur V.K. (2014) Medical Applications of Cellulose and its Derivatives: Present and Future, in Nanocellulose Polymer Nanocomposites: Fundamentals and Applications (ed V. K. Thakur), John Wiley \& Sons, Inc., Hoboken, NJ, USA.

Son H.J., Kim H.G., Kim K.K., Kim H.S., Kim Y.G. and Lee S.J., Increased production of bacterial cellulose by Acetobacter $s p$. V6 in synthetic media under shaking culture conditions, Bioresource Technology. 86, No. 3, 215 (2003)
Usha R.M. and Anu A.K.A., Gluconacetobacter hansenii UAC09-mediated transformation of polyphenols and pectin of coffee cherry husk extract, Food Chemistry, 130 No. 2, 243 (2012).

Wu Z.Y., Li C., Liang H.W., Chen J.F. and Yu S.H., Ultralight, flexible, and fire-resistant carbon nanofiber aerogels from bacterial cellulose, Angewandte Chemie International Edition, 52, No. 10, 2925 (2013)

Yasuhara T. and Nokihara K., High-throughput analysis of total nitrogen content that replaces the classic Kjeldahl method, Journal of Agricultural and Food Chemistry, 49, No. 10, 4581 (2001).

Young, J.W., Isolation and characterization of a bacterial cellulose-producing bacterium derived from the persimmon vinegar, African Journal of Biotechnology, 10, No. 72, 16267 (2011).

Zeng X., Small D.P. and Wan W., Statistical optimization of culture conditions for bacterial cellulose production by Acetobacter xylinum BPR 2001 from maple syrup, Carbohydrate Polymers, 85, No. 3, 506 (2011). 